\title{
Article
}

\section{Is South Korea's Green Job Policy Sustainable?}

\section{Yeon-Mi Jung}

Center for German and European Studies, Chung-Ang University, Hekseok-ro 84, Dongjak-gu, Seoul 156-756, Korea; E-Mail: ymjung@cau.ac.kr; Tel.: +82-2-820-6537

Academic Editor: Marc A. Rosen

Received: 19 May 2015 / Accepted: 2 July 2015 / Published: 6 July 2015

\begin{abstract}
South Korea's green job policy was implemented in February 2008 as a part of low-carbon green growth policy, but has been discontinued at the present. The country's actual energy and environmental consumption has continuously increased, and South Korean society has grown increasingly distant from sustainable development. The study constructs a theoretical framework centering on sustainable development and analyzes the process and contents of South Korea's green job policy. We suggest four findings: First, in terms of ideology, the nation's green job policy was based on green growth. Implemented as a strategy typical of developing countries, South Korea's green growth was pursued as weak ecological modernization, relatively stressing economic growth and excluding citizens' participation. Second, in terms of governance, the nation's green job policy was led by the central government, thus nearly completely destroying existing legal and institutional infrastructures related to sustainable development. Third, South Korea's green job policy was defined on the basis of a growth orientation and concentrated on the Four Major Rivers Restoration Project and the NPP project, both of which betrayed considerable problems from the perspective of sustainable development. Fourth, green jobs were created in traditional environmental protection and pollution reduction and therefore limited.
\end{abstract}

Keywords: green jobs; green growth; sustainable development; ecological modernization; green economy; green new deal

\section{Introduction}

Today, methods of economic growth that depend on fossil energy such as petroleum, coal, and natural gas $(\mathrm{NG})$ have led to climate change unprecedented in human society due not only to advanced nations, whose economies have gone beyond the mature stage, but also to the dramatic economic 
development in recent years of developing countries such as China and India, which consume considerable energy. Considering the clear warnings sent by the meteorological system and the fact that humans are the major cause of climate change, the Earth currently faces a crisis. To avoid the worst outcome of climate change, the breadth of the world average temperature rise must be suppressed within $2{ }^{\circ} \mathrm{C}$. Because global warming has led to serious, widespread, and unavoidable results, the later sustainable production and consumption are begun, the social costs will increase even further. The major reason for climate change is carbon dioxide $\left(\mathrm{CO}_{2}\right)$, whose emission humans have caused. Methods of economic growth that depend on fossil energy not only emit $\mathrm{CO}_{2}$ but also have led to the gradual depletion of natural resources and their consequential unstable supply to the international market, thus periodically serving as a factor for economic instability. Current economic growth methods exploit fossil fuel, which is a limited resource, and the atmosphere's ability to store carbon and continuously increase human society's global demand for such resource. As a result, they propel even more production and consumption, thus destroying the equilibrium of the ecosystem. Floods, droughts, windstorms, and sea level rise, which can be triggered by climate change, will lead to damages beyond levels historically experienced by the human race so far, and, in fact, it is still unclear as to just how destructive the results will be.

In the case of South Korea, according to predictions by the National Institute of Environmental Research (NIER), by 2050, the country's temperature, annual precipitation, and sea level are expected to increase by $3.2^{\circ} \mathrm{C}, 15.6 \%$, and $27 \mathrm{~cm}$, respectively. While the Earth's average temperature has risen by $0.89{ }^{\circ} \mathrm{C}$ over the past 112 years, the temperature rise for South Korea during the same period has been $1.7{ }^{\circ} \mathrm{C}$, twice as high. If the nation continues to emit greenhouse gases (GHG) at current rates without reduction, the figure is expected to increase by $5.9^{\circ} \mathrm{C}$, again twice as high, and sea level rise likewise surpasses the world average. In particular, because of a change into a subtropical climate, the vulnerability of Northeast Asia including the Korean Peninsula to the effects of climate change including the destruction of social infrastructures due to floods, deaths due to heat waves, and shortages of water and food due to droughts is expected to be higher than the world average. Indeed, climate change has affected the economy of the Korean Peninsula considerably as well [1].

Amidst such a situation, South Korea's energy-intensive economic growth and environmental pollution have accelerated. The nation's energy use and GHG emission has continued to increase along with economic growth since the implementation of the first 5-Year Economic Development Plan in 1962, when full-fledged industrialization began. South Korea's economy has grown rapidly, even giving rise to the neologism "Miracle on the Han River". However, because it has focused only on short-term economic gain, the country is now witnessing in all spheres of society the side effects and limitations of intensifying problems including environmental pollution, inequality, economic gap, and corruption. At this moment, the decoupling of South Korea's economic growth and GHG emission seems extremely difficult. Indeed, from 2007 to 2015, the increase rate for GHG emission surpassed that of the gross domestic product (GDP). Despite its short history of industrialization, the nation ranks 7th worldwide (19th cumulatively) in GHG emission and 1st worldwide in the GHG emission increase rate, respectively. Moreover, it imports $97 \%$ of its necessary energy from other countries. In fact, South Korea's total energy import far surpasses its export of automobiles, steel, and ships combined. Although the country now ranks 13th worldwide in economic size and 8th worldwide in trade volume, respectively, it also ranks 4th globally in energy import. With energy efficiency according to energy 
intensity of GDP half that of the Organization for Economic Cooperation and Development (OECD) and one-third that of Japan, respectively, South Korea must remedy such a situation for many reasons. However, measures have not been properly taken due to reasons including the price competitiveness of the domestic industries and the management of commodity prices. This is in contrast to advanced countries such as Germany and Denmark, which have pursued the desynchronization of economic growth, environment, and energy consumption as a national strategy and reaped considerable fruits [2].

According to Statistics Korea (KOSTAT) and OECD, South Korea's unemployment rate has increased by $1.1 \%$ points from $2.4 \%$ in 1990 to $3.5 \%$ in 2014 . In February 2015, South Korea's unemployment rate of $4.6 \%$ and youth unemployment rate of $11.1 \%$ were at their highest since the Asian financial crisis of 1997 . The actual unemployment rate including abdicant employment is $12.5 \%$. The gap of the youth unemployment rate compared to the entire unemployment rate has continued to expand since 2012 and reached 6.5\% points in February 2015, surpassing the 5.6\% points at the end of 1998, the highest figure ever. South Korea has thus witnessed the intensification jobless growth, whereas economic growth continues but the capacity to create jobs increasingly drops $[3,4]$.

On the other hand, due to the global economic crisis during the latter half of 2008, which fundamentally shook up the framework of the capitalist market economy, a trend of low economic growth and low interest rates has become fixed, thus further aggravating the world market. Recent years have witnessed a phenomenon where jobs do not increase even with investment or economic growth. Due to "growthless jobs" and "jobless growth," where the economic growth and employment do not go hand in hand, faith in the traditional employment policy that the promotion of investment and growth creates jobs has been shattered. In addition, youth unemployment rates have increased around the world. As a result, green job policy has become as important as never before because it links the problems of environmental crisis including climate change, which has emerged as a global issue in the 21 st Century, economic growth, and employment. In the past, environmental protection was seen as a factor that raised costs and interfered with growth. However, it has now been evaluated as having the potential to promote technological innovation, to create jobs, and to enhance both the economy and welfare in the green economy of the future. In such a context, international discussions on green jobs have been active. The governments of various countries have endeavored to devise measures regarding green jobs. In particular, because the economic crisis of 2008 led to a rise in unemployment, poverty, and inequality, more people voiced concerns arguing that returning back to the employment situation before the economic crisis is not enough for economic recovery, environmental conservation, and decent employment for everyone and that it is increasingly more vital to find alternative ways of promoting employment.

However, because no country has had enough time since the implementation of its green job policy to make objective evaluations, as of 2015 , the success or failure of green job policy remains an unfinished process [5-8]. However, one thing is clear: to realize increased employment and environmental conservation through the creation of green jobs, an ideological foundation for sustainable development and active, consistent policy signals based on it are necessary. Each country has implemented green job policy based on a disparate ideological foundation in accordance with its social, political, and economic situation. The green job policy of advanced nations closely links the two challenges of actively responding to environmental problems such as climate change and of creating quality jobs from the perspective of sustainable development and starts from the recognition that the problems of 
environmental conservation, economic growth, and employment creation cannot be addressed separately. In contrast, the green job policy of developing countries tends mainly to be biased in favor of economic growth [9].

In such a context, South Korea's green job policy is an interesting research topic. Following the launching of the Lee Myung-bak administration in February 2008, the nation saw the implementation of green job policy for the first time. At the time, the Lee Myung-bak administration pursued green job policy, presenting "low-carbon green growth" as the national vision. At this moment, however, green job policy has lost its momentum and come to a standstill, not even mentioned in policy documents. Since the launching in February 2013 of the Park Geun-hye administration, which has espoused the "creative economy" as the new national vision, green job policy has remained in a stalemate without being a practical alternative to sustainable development, and an economic growth orientation through market self-regulation has continued to be in effect. As a result, contrary to the past praise abroad for South Korea's green growth policy [10,11], the nation's energy and environmental consumption has in fact continued to increase, and the country has grown increasingly distant from sustainable development.

Starting from such problematics, the present study will construct a theoretical framework centering on sustainable development and analyze the process and contents of South Korea's green job policy. First, it will analyze the process through which this green job policy was introduced, grew, came to a halt, and reached the current rupture. The present study will then analyze the contents of the nation's green job policy in terms of the theoretical foundation, governance, definitions, and scale. Following Section 1, the introduction, Section 2 will construct a theoretical framework for analysis, with a focus on sustainable development. Section 3 will analyze the moments at which the green job policy was introduced, grew, became stagnant, and stopped. Section 4 will analyze the contents of the green job policy in terms of the ideological foundation, governance, definitions, and scale. Section 5 will present the conclusion and policy implications.

\section{The Theoretical Framework for Analysis: The Meaning of Green Jobs in Sustainable Development}

For the protection of the Earth's planetary boundaries, it is necessary to construct a renewable and efficient energy system and to promote economic growth that does not cause the qualitative deterioration of the environment. To achieve this, it is necessary to bring about an ecological transformation of the economy that will guarantee sustainable production and consumption. The problematics that the human race will face ecological, economic, social, and political limits and stop growth if unsustainable growth is continued as at present has developed continuously since the publication of The Limits to Growth by the Club of Rome in 1972.

Since the World Commission on Environment and Development (WCED) explicated sustainable development in a report titled "Our Common Future: Report of the World Commission on Environment \& Development" in 1987, sustainable development has become a dominant discourse in international environmental politics. The concept of sustainable development signifies "intergenerational equity", which stipulates that the needs of current generations must be satisfied without damaging the environment and nature to be used by future generations, and "development within the environmental capacity," which stipulates that pollutants must be released within the scope of nature's capacity for 
purification when using the natural environment and resources. A normative concept with a spectrum that expands not only to the economic dimension but also to the environmental and social dimensions, sustainable development stresses that the problem of economic growth cannot be separated from those of environmental pollution and resource depletion. Sustainable development aims at finding paths of sustainable development not only locally but also globally, and combines environmental interest and economic and social interests [12].

It has been over 20 years since world leaders gathered in Rio de Janeiro in 1992 to find ways to collaborate as regards environmental politics for international cooperation on sustainable development. Over the past 20 years, countries around the globe have made efforts for sustainable development. With intensifying climate change, resource depletion, inequality, poverty, and destruction of nature despite the brilliant material growth achieved in the 20th Century, in the 21 st Century, the human race has come to face the so-called "paradox of development", where ways of surviving must be pondered on, going beyond the level of simple environmental protection. According to the report "Keeping Track of Our Changing Environment: From Rio to Rio + 20 (1992-2012)" published at the United Nations Conference on Sustainable Development (UNCSD; Rio + 20) in 2012, environmental inequality has worsened and the Earth's environment still does not seem to have attained sustainable development even as the world GDP increased by $75 \%$ and the per capita GDP increased by $40 \%$, respectively, over the past 20 years $[13,14]$.

In recent years, ideas on sustainable development have been formulated as concepts including "green jobs", "green growth", "green economy", and "Green New Deal" [11,15,16]. From among these, the present study focuses on green jobs. When definitions of green jobs in earlier studies on green jobs conducted by the governments of diverse countries, international organizations, research institutes, labor unions, and non-governmental organizations (NGOs) worldwide are examined, there is no single unified, theoretical definition of green jobs. However, all parties generally and commonly find the ideological foundation for green jobs in sustainable development. With the destruction of the Earth's environment and the escalation of the energy crisis today due to problems including climate change, extinction of biological species, decrease in biodiversity, depletion of fossil fuel, Nuclear Power Plant (NPP) accidents, and radioactive contamination, interest in sustainable development as a normative and discursive concept has continued to increase, with a focus on advanced member nations of the OECD [9,17-19].

From the perspective of sustainable development, green jobs hold the following significance. First, green jobs have a normative level, going beyond the paradigm of the existing labor market, where problems with employment and unemployment are resolved simply though unemployment countermeasures aimed at economic stimulation or economic growth, reducing environmental and energy consumption, and pursuing economic growth methods that do not cause the qualitative deterioration of the environment. Green jobs are a part of the process of radically changing the economy today, which leads from mass production to mass consumption to mass disposal, so that it will function within the Earth's ecological limits. Today, the inefficient use of resources and economic growth based on increased economic pressure on the environment are causing problems of sustainability and demand action for changes to growth models in the long run. Consequently, green jobs are being reviewed not only as a short-term employment measure but also as a long-term, alternative developmental model that will replace existing economic growth paradigms. 
Second, green jobs make clear the limits of the ecosystem and consider not only the quantity but also the quality of jobs. Green jobs signify jobs that not only save energy and resources, realize low-carbon emissions, and reduce pollution on a quantitative dimension but also protect biodiversity and the ecosystem and contribute to the maintenance or recovery of the environment's qualitative level on a qualitative dimension. Green jobs signify not only greening existing fields with jobs but also continuously creating jobs in new green fields such as renewable energy, energy efficiency, and environmental services. Consequently, green jobs do not simply increase the number of jobs but demand environment-related skills that will heighten green investment and productivity and aim at public values common to society. From such a perspective, green jobs correspond to sustainable development, which stresses a balance among the economy, environment, and social justice.

Third, green jobs are good or decent jobs that respect the value of both nature and humans and contribute to human development. Sustainable development signifies not only economic, environmental, and social development but also human development. While pursuing the promotion of the welfare of current generations under the goal of sustainable development, green jobs simultaneously considers the welfare of future generations as well. Green jobs are one of the important means of guaranteeing and realizing happy and sustainable life for the entire human race. Those who hold green jobs can feel proud and satisfied that their work is for the Earth and the environment and, moreover, contributes to humanity. Human development goes beyond resolving the problem of unemployment on a microscopic level and provides chances to improve the quality of life (QoL) of humans by qualitatively enhancing human capital through linkage with demand in the labor market on a macroscopic level. Increasing unemployment not only incurs economic and social costs in the future but also threatens the core of society and is an important component of sustainable development. Consequently, the importance of green jobs continues to increase as a measure to decrease unemployment among senior citizens, women, youths, disadvantaged groups, and local residents for sustainable development.

\section{An Analysis of the Process of South Korea's Green Job Policy}

South Korea's green job policy was implemented in earnest under the basic "low-carbon green growth" policy of the Lee Myung-bak administration, which was launched in February 2008. Inaugurated on 25 February 2008, the Lee Myung-bak administration presented "low-carbon green growth" as the "Vision for New 60 Years" upon the 60th anniversary of national foundation in the congratulatory speech delivered on 15 August 2008 (Liberation Day). Low-carbon green growth was growth that would reduce GHG and environmental pollution and presented as the paradigm for new national development that would prepare new growth engines and create works through the development of green technology (GT) and clean energy. The low-carbon green growth mentioned by President Lee Myung-bak in the congratulatory address on Liberation Day is as follows:

"Today, when we mark the 60th anniversary of the foundation of the Republic of Korea, I would like to present low-carbon green growth as the axis of a new vision. Green growth is sustainable growth that will reduce greenhouse gases and environmental pollution. It is the paradigm for new national development that will create new growth engines and jobs through green technology and clean energy." 
Domestically, the Presidential Committee on Green Growth, to be in charge of the entire project, would be created, and the implementation system for the green growth policy would be established with the legislation of the Framework Act on Low Carbon, Green Growth. In November 2008, President Lee Myung-bak instructed the establishment of the green growth implementation system. In December of the same year, a planning group was inaugurated to prepare for the creation of the Presidential Committee on Green Growth. In January 2009, with the relevant law not yet enacted, the Presidential Committee on Green Growth was established based on a Presidential directive. Once the Presidential Committee on Green Growth was in place as an organization capable of managing the Lee Myung-bak administration's green growth policy, the task of preparing the relevant law began around the committee. In February 2009, the government's draft of the law was confirmed under the name of "Framework Act on Low Carbon, Green Growth". As diverse legal problems were raised, the bill was finally passed in the National Assembly on 29 December 2009 after 10 months of discussions, thereby assuming the legal basis as a framework act. Green growth thus came to stop being a policy statement and to be settled as a substantial institution. In July 2009, the National Strategy for Green Growth, which was targeted for the year 2050, and the Five-year Green Growth Plan, which would be implemented during President Lee Myung-bak's term of office, were both announced [20].

To implement the national green growth strategy for 5 years (2009-2013), the Lee Myung-bak administration established three strategies to be put into practice: first, the creation of new growth engines; second, adaptation to climate change and the realization of energy independence; and, third, the improvement of the QoL and the strengthening of national standing abroad. For these national green growth strategies, Green New Deal Project and the new growth engine project including the Green New Deal Project, priority GT development and commercialization plan, and national green information technology (IT) strategy were implemented [21,22]. South Korea's green growth policy was largely divided into a comprehensive plan and a sectoral plan. The comprehensive plan consisted of the national green growth strategy, 5-year plan, and action plan per government organization. The sectoral plan consisted of the key plan and the linked plan. Directly related to green growth, the key plan was to be established at a Cabinet meeting after deliberation by the Presidential Committee on Green Growth. The linked plan was a plan indirectly related to green growth, and its scope was determined by the Enforcement Decree of the Framework Act on Low Carbon, Green Growth [23].

Because green growth was presented as a solution to and amidst the situation of the world financial crisis at the time, it was necessary to concretize projects in the Green New Deal as green job policy. Consequently, the South Korean government announced in January 2009 a detailed execution plan titled "A Plan to implement the 'Green New Deal Project' for the Creation of Jobs". Specifically, a plan was established so that, with a focus on 9 key projects and 27 linked projects that were closely related to the environment out of the South Korean version of the New Deal and new growth engine projects, 50 trillion won would be invested in the Green New Deal up to 2012 to create 950 thousand jobs. Out of the total budget of 50 trillion won for the Green New Deal, the largest share, 15 trillion won, was taken up by the Four Major Rivers Restoration Project [24]. Subsequently, South Korea was introduced internationally as a model of the Green New Deal. However, with the domestic disclosure of the fact that the Four Major Rivers Restoration Project and the NPP project were included in green growth, oppositional campaigns by civil society organizations (CSOs) began and many social debates surfaced. 
On the other hand, because the Lee Myung-bak administration had internationally declared that it would lead GHG reduction, on 17 November 2009, the South Korean government established and announced at a Cabinet meeting the mid-term GHG reduction goal, whereby GHG would be reduced by $30 \%$ with respect to business as usual (BAU) emissions by 2020 and which were unprecedented in history. As concrete policy instruments for achieving the national GHG reduction goal, the following systems were introduced: the GHG goal management system in 2011, with 434 businesses emitting large amounts of GHG (these took up approximately $61 \%$ of total national emission) as the objects; the renewable portfolio standard (RPS) system in 2012; and the GHG emission trading system in 2015, respectively [25]. By establishing the mid-term GHG reduction goal and introducing the GHG goal management system, the Lee Myung-bak administration was able to highlight its image as a leading country actively responding to climate change internationally and to quiet down citizens' campaigns against the additional installation of NPPs, extension of the lifetime of old NPPs, construction of transmission towers, and Four Major Rivers Restoration Project domestically. In the end, from 2008 to 2010, institutionalization for low-carbon green growth was implemented swiftly domestically, and, with the designation of South Korea as a model of the Green New Deal pursued by the UN and the OECD internationally, the low-carbon green growth policy was strengthened both at home and abroad, thus forming the backdrop against which the green job policy came to be implemented.

With the expansion of the world financial crisis at the time, internationally, the OECD and the UN made the theory of green growth official as a plan capable of simultaneously resolving the financial crisis and the environmental crisis as represented by climate change, thus initiating global discussions. At the OECD ministerial meeting held in June 2009, the OECD agreed to develop green growth strategies. Under the leadership of South Korea, which was serving as the chair of the Ministerial Council Meeting (MCM) at the time, the OECD came to adopt the Declaration on Green Growth [26]. In April 2009, the UN Environmental Program (UNEP) began to stress the Green New Deal as a solution capable of resolving the current financial crisis and environmental crisis [15]. In fact, this concept was rooted in "Green New Deal" published in July 2008, a step ahead of the UNEP, by the New Economics Foundation (NEF) in the United Kingdom [27]. Because of all of this, it was possible for the concept of the Green New Deal to receive high praises from advanced countries such as the United States, Japan, Germany, and France.

The UNEP has evaluated South Korea's green growth policy favorably. "Seizing the Green Opportunity," its annual report for 2009, introduces the country as one with the environment taking up the highest proportion in government expenditure for economic recovery $(81 \%)$, followed by the European Union (EU; 64\%), China (34\%), and Australia (21\%). Some scholars also consider South Korea to be a green growth state which has achieved progress in environmental policies [10,28-30]. In April 2010, the UNEP issued a separate report on South Korea titled "Overview of the Republic of Korea's National Strategy for Green Growth". This report positively evaluated the fact that a considerable part of South Korea's economic stimulation policy had been green expenditure. It evaluated the Four Major Rivers Restoration Project, which has been the object of considerable social debate domestically not only at the time but even today, as a model case of green growth in restoring rivers and introduced South Korea as a model of the Green New Deal [11].

Internationally, interest in the Green New Deal and green jobs has not dwindled. With the continuation of the world financial crisis begun in 2008, solutions regarding green jobs are still valid. 
In addition, the "green economy" has continued to be discussed as a concretized concept of sustainable development in the international community through Rio +20 . However, South Korea's green job policy has betrayed considerable discontinuity since the inauguration of the Park Geun-hye administration. Amidst the government's recent implementation of short-term job projects such as social employment projects and internships at subordinate organs without the sufficient presentation of fundamental solutions, the green job policy lies in a stalemate.

\section{An Analysis of the Contents of South Korea's Green Job Policy}

\subsection{The Ideological Basis}

South Korea's green job policy is based ideologically on a growth orientation as represented by "low-carbon green growth". Green growth became public knowledge with the publication in the Economist of a Yale University study presented at the World Economic Forum (WEF) on 29 January 2000. In South Korea, green growth is a comparatively recent concept, presented in the mid-2000s. The concept became known in the country with the adoption of the Seoul Initiative Network on Green Growth (SINGG) at the Ministerial Conference on Environment and Development (MCED) held in Seoul in 2005. The gist of the declaration, led by the United Nations Economic and Social Commission for Asia and the Pacific at the time [31,32], was to pursue more environment-friendly economic growth, with the environmental problems stemming from the compressed economic growth achieved by South Korea as counterexamples [20].

According to government documents, South Korea's green growth policy is based theoretically on sustainable development and ecological modernization [24]. Ecological modernization is a representative argument which links environmental conservation with economic development and aims on the simultaneous achievement of both values. Ecological modernization gathered ground in the 1980 s, as environmentalism departed from its negative view towards modernization. According to the ecological modernization theory, simultaneous progress in economic development and environmental conservation is possible when new technology that does not cause pollution is developed and distributed, substituting the technology in the past which caused pollution or passively prevented it. That is, just as labor and capital productivity had been the source of development, environmental productivity could be the source of development in the future. Some scholars distinguish two different views on ecological modernization: "strong" ecological modernization and "weak" ecological modernization [33-36]. However, there are many debates and differences among researcher as to whether the Lee Myung-bak administration's green growth was a concept that had inherited sustainable development and could be evaluated as a part of ecological modernization. According to the Presidential Committee on Green Growth, green growth is a concept where economic growth must be pursued but economic growth patterns are to be changed to be environment-friendly. Green growth is defined as "harmonized development of the economy and environment" (Article 1, Framework Act on Low Carbon, Green Growth) and sustainable development is defined as "development based on sustainability that is implemented simultaneously in the pursuit of economic growth, social stability and integration, and the preservation of the environment" (Article 2, Sustainable Development Act), 
respectively. The Presidential Council for Future and Vision, which led the green growth policy, stated, "Green growth is a practical strategy for arriving at sustainable development" [37].

From the perspective of sustainable development and ecological modernization, South Korea's green growth policy has the following ideological characteristics (Table 1). First, green growth is a concept below that of sustainable development both theoretically and according to the nation's positive law. A concept encompassing both the environment and growth, green growth seeks to transform the economic growth paradigm to be environment-friendly yet is clearly distinguished from sustainable development. In that it clearly presents the limits of the ecosystem as those of economic growth and places the issues of distribution and social justice before growth, sustainable development can be understood as a concept that pursues not only a balance between economic growth and environmental conservation but also social justice and equality. Whereas sustainable development is a desirable strategy that thus simultaneously pursues economic growth, environmental conservation, and social justice, South Korea's green growth remains a narrow concept that disregards social justice and only pursues economic growth and environmental conservation [20,27,38].

Second, South Korea's green growth policy exhibits little conceptual difference from the green growth strategy of developing countries. South Korea's green growth policy is a strategy adopted at a particular stage of national development: the "theory of Asian sustainable growth", which is a developing countries' strategy that excludes elements of social justice and focuses only on environmental protection and economic growth [39,40]. In other words, green growth is a model appropriate for developing countries because, by conceptually excluding the democratic participation of social groups, it can create a political environment that is more advantageous for developing countries with a low degree of democratization to pursue economic growth. A document drawn up by the Ministry of Knowledge Economy, which is one of South Korea's government ministries responsible for green growth, likewise describes green growth as a strategy basically for developing countries. The Ministry of Knowledge Economy [41] explains: “The Lee Myung-bak administration's low-carbon green growth is not an environment strategy applied to low-development nations but an economic development strategy for growth into an advanced nation by making use of the energy and environmental crises as an opportunity". The South Korean government's statement that this strategy aims at the country's "growth into an advanced nation" demonstrates that it still perceives itself as a developing country.

Third, South Korea's green growth can be seen as weak ecological modernization, which places relatively more emphasis on economic growth, and is removed from strong ecological modernization, which is characterized by systemic changes in the base of society. The South Korean government, too, is aware of such limitations. According to the 2012 work plan of the Presidential Committee on Green Growth, problems with the green growth policy include: insufficient understanding and praxis among the people regarding the itemized issues of green life; insufficient implementation systems among and within government ministries; and insufficient partnership among NGOs, local governments, and politicians [42]. Even in terms of the composition of the Presidential Committee on Green Growth, civil society's participation in policy decisions is limited because CSOs are not specified as candidates for commissioned members [27]. 
Table 1. Comparison of sustainable development and green growth.

\begin{tabular}{lll}
\hline Classification & Sustainable Development & Green Growth \\
\hline Organ & UNCSD & UNESCAP \\
\hline Impetus & Our Common Future (1987) & UN MCED (2005) \\
\hline Objects & Countries around the world & Countries in the Asia-Pacific \\
\hline \multirow{2}{*}{ Background } & $\begin{array}{l}\text { Eradication of environmental pollution, a result } \\
\text { of growth }\end{array}$ & $\begin{array}{l}\text { Prevention of environmental pollution at } \\
\text { the growth stage }\end{array}$ \\
\hline \multirow{2}{*}{ Purpose } & $\begin{array}{l}\text { Simultaneous pursuit of economic growth, social } \\
\text { development, and environmental protection }\end{array}$ & $\begin{array}{l}\text { Securement of both the overcoming of } \\
\text { poverty and environmental sustainability }\end{array}$ \\
\hline
\end{tabular}

Source: [41].

\subsection{Governance}

South Korea's green job policy was pursued by the central government as a priority project for realizing the Lee Myung-bak administration's nation vision of low-carbon green growth. Preempting green growth as a national agenda and presenting the legitimate duty of a growth-fixated state whose highest national goal was economic growth, South Korea forced the implementation of a top-down economic growth policy led by the central government. Through a strategy of converting nature, which is a production condition necessary for economic growth, into a resource and using the discourse of green growth and green jobs, where growth and employment would be expanded through green jobs, the South Korean government excluded the policy participation of diverse social groups regarding issues such as the Four Major Rivers Restoration Project and the NPP project. This central government-led green growth strategy, where the state subsumed its environmental duty by linking only its economic duty of economic development to its legitimate duty, lacked an ecological and environmental understanding. Although the country espoused "green" on the surface, it established all of its strategies in terms of growth in essence and, in terms of the implementation methods, betrayed the continuation of a growth orientation in the form of industrialization led by the central government.

Such characteristics of South Korea's green growth policy are typical of both capitalist development states (CDS) and dirigiste capitalism [43,44]. Some scholars classify such systems as "construction states" or "neo-developmentalism" as well. They are called "construction states" in that the state perform social coordination in an authoritarian manner to accumulate capital and its development orientation manifests itself mainly through large-scale national projects or local development projects $[45,46]$. In addition, because development is actually encouraged more despite the superficial espousal of the value of environmental conservation, such phenomena are also called instances of "neo-developmentalism" [47,48]. Such an authoritarian and state-led social coordination process and the nature of a development-oriented state likewise affected the process of implementing the green growth policy [45-48].

The legal basis of the green growth policy was the Framework Act on Low Carbon, Green Growth, and the Presidential Committee on Green Growth was the central administrative organization. Legislated in January 2010, the Framework Act on Low Carbon, Green Growth was a higher law to be applied first, before other laws as far as green growth was concerned. Even though sustainable development is a higher concept and green growth is a lower concept, the existing Framework Act on Sustainable Development was changed into the Sustainable Development Act. Moreover, with the 
demotion of the Framework Act on Energy to the Energy Act, the policy principles and directions of the existing framework act were transferred to the Framework Act on Low Carbon, Green Growth, and diverse climate change bills whose legislation had been under way were suspended and their contents were absorbed by the Framework Act on Low Carbon, Green Growth. By being legislated on the level of national development strategy, the Framework Act on Low Carbon, Green Growth stipulated a considerable variety and scope of policies. In September 2000, under the Kim Dae-jung administration, the Korean National Commission on Sustainable Development had been established directly under the President. In August 2007, the Framework Act on Sustainable Development had been legislated. With the legislation of the Framework Act on Low Carbon, Green Growth, however, the two existing framework acts were incapacitated, not only bringing about confusion in the legal system through the legislation of one framework act on top of another but also nearly eradicating legal and institutional infrastructures regarding sustainable development [49,50]. In fact, it is almost unprecedented worldwide for a single law to encompass a wide range of issues including GHG, energy, land, environment, and economic growth [38]. Under such a legal implementation system, South Korea's green job policy was trapped in the paradigm of low-carbon green growth, thus not quite reaching the ecological transformation of the economy.

\subsection{Definitions}

Research institutes and organs worldwide define green jobs disparately, in the context of their respective societies. Consequently, the task of defining green jobs can be said to be an ongoing one. In the case of South Korea, "green industries" themselves are not defined in the Korean Standard Industrial Classification (KSIC). The table below (Table 2) shows the various definitions of green jobs. When existing studies both from home and abroad were reviewed and definitions of green jobs were examined, South Korean research institutes turned out to define green jobs based on growth. The Ministry of Strategy and Finance, etc. [21] defines green jobs as jobs that contribute to low-carbon green growth. The Korea Labor Institute [51] defines green jobs in both the narrow and broad senses after dividing them by industry and occupation. Green jobs are defined as jobs for low-carbon green growth in the narrow sense and as jobs generated through environment-friendly economic growth in the broad sense, respectively. The Korea Employment Information Service [52] defines green jobs as the production of goods or the provision of services related to humanity's sustainable growth through GHG reduction and the protection of the Earth's environment and ecosystem. 
Table 2. Definition of green jobs.

\begin{tabular}{ll}
\hline \multicolumn{1}{c}{ Organ } & \multicolumn{1}{c}{ Definition } \\
\hline UNEP (2008) & $\begin{array}{l}\text { Jobs that contribute sustainability to preserving or restoring environmental quality; protect and } \\
\text { restore ecosystems and biodiversity; reduce energy, materials, and water consumption through } \\
\text { high-efficiency and avoidance strategies; decarbonize the economy; minimize or altogether } \\
\text { avoid generation of all forms of waste and pollution }\end{array}$ \\
\hline U.S. Bureau of Labor & $\begin{array}{l}\text { Jobs that produce goods or provide services that benefit the environment or conserve natural } \\
\text { resources; produce more environmentally friendly; use fewer natural resources }\end{array}$ \\
\hline EC (2012) & Jobs in the environmental field or requiring environment-related skills \\
\hline $\begin{array}{l}\text { Ministry of Strategy and } \\
\text { Finance, etc. (2009) }\end{array}$ & $\begin{array}{l}\text { Jobs contributing to low-carbon green growth through the production of goods or provision of } \\
\text { services that can increase the efficiency of energy and resources across the industries and } \\
\text { improve the environment }\end{array}$ \\
\hline $\begin{array}{l}\text { Korea Employment } \\
\text { Information Service (2010) }\end{array}$ & $\begin{array}{l}\text { Jobs that produce goods or provide services related to GHG reduction, protection of the Earth's } \\
\text { environment and the ecosystem, and humanity's sustainable growth }\end{array}$ \\
\hline $\begin{array}{l}\text { Korea Labor Institute } \\
\text { (2010) }\end{array}$ & $\begin{array}{l}\text { In the narrow sense, occupations in industries aimed at low-carbon green growth and defined as } \\
\text { for jobs generated from environment-friendly economic growth including jobs that play } \\
\text { environment-friendly functions across all industries and diverse occupations that cause } \\
\text { employment in the process of industrial reorganization for green growth }\end{array}$ \\
\hline
\end{tabular}

Sources: $[18,21,51,53]$.

In contrast, the worldwide trend in green job policy is based on a definition of green jobs that starts from sustainable development including the qualitative aspect of jobs and the recovery of biodiversity and the ecosystem. The UNEP defines green economy as one that "respects natural and human value and creates good jobs with appropriate wages" and, from the perspective of green economy, proposed the Global Green New Deal in 2008 as one means of overcoming the economic crisis. The UNEP report on green jobs was drawn up jointly by the International Labor Organization (ILO), International Trade Union Confederation (ITUC), International Organization of Employers (IOE), and European Trade Union Confederation (ETUC). It defines green jobs as decent, humane jobs created in agriculture, manufacturing, $R \& D$, management, and services to reduce the many environmental threats facing the human race. On the other hand, as for the scope of green jobs, they are described as occupations that contribute to the maintenance or recovery of the qualitative level of the environment through functions such as protecting biodiversity and the ecosystem, reducing energy and resources, realizing low-carbon emissions, and reducing contamination and as occurring across a wide range of fields including agriculture, manufacturing, construction, process industry, $\mathrm{R} \& \mathrm{D}$, administrative and clerical work, and services. The European Commission (EC) defines green jobs as jobs in the environmental field or requiring environment-related skills [18].

South Korea has distorted the estimation of green jobs by classifying as green industries the NPP project and the Four Major Rivers Restoration Project, which have exhibited numerous problems from the perspective of sustainable development and continued to be criticized even today, defining green jobs accordingly, and estimating their scale. Whether the Four Major Rivers Restoration Project and the NPP expansion project can be seen as green growth projects continues to be the object of considerable social debate, and these two projects have betrayed many problems from the perspective 
of sustainable development $[20,27,40,54]$. Nevertheless, with the implementation of the central government-led low-carbon green growth policy, the Four Major Rivers Restoration Project was selected as a Green New Deal project and the NPP project was selected as a green energy fostering project for GT, respectively. Thus, defining and estimating green jobs with the inclusion of the Four Major Rivers Restoration Project and the NPP project not only seriously distorts the estimation of green jobs in South Korea but also is inappropriate in light of the worldwide trend in the definition of green jobs. With the UN and major advanced countries, the key to green jobs lies in increasing renewable energy and energy efficiency. The most frequently cited UNEP report on green jobs proposes ecological tax reforms to expand green jobs, introduction of innovative policy instruments to expand renewable energy, reduction of resources regarding nuclear power and fossil fuel, and expansion of support to increase renewable energy and energy efficiency [17].

\subsection{Scale}

Because South Korea's definition of green jobs is biased toward growth in contrast to the worldwide trend, the scale of green jobs in the nation turned out to be overestimated when estimates were made. Seeing industries that implemented projects in the green growth policy based on the contents of the Framework Act on Low Carbon, Green Growth as green industries, government-funded research institutes estimated the employment creation effect of green jobs. Mainly energy and environmental protection was classified as a major green industry.

The scale of green job creation announced by the South Korean government amounts to 950 thousand-542 thousand. In "A Plan to Implement the 'Green New Deal Project' for the Creation of Jobs" of January 2009, the South Korean government announced a plan to create 950 thousand jobs by investing 50 trillion won up to 2012 in the Green New Deal, with a focus on 9 key projects and 27 linked projects closely related to the environment out of the South Korean version of the New Deal and new growth engine projects. On the other hand, the Ministry of Strategy and Finance, etc. [21] divided green jobs into a total of five fields - high efficiency of energy sources and energy, greening of the industries and spaces, environmental protection and resource circulation, and low-carbon economic activities - and analyzed that, as of 2008, the scale of green jobs amounted to 611 thousand (Table 3). However, with the groups in the KSIC (228), classes in the Korean Standard Classification of Occupations (KSCO; 426) in the Occupational Employment Statistics (OES) used at the time, it is impossible to distinguish between green industries and non-green industries. When the contents of the groups in the KSIC are examined, as industries related to new and renewable energy, there are the "manufacture of electrical equipment $[\mathrm{s}]$ " including the manufacture of generators and electric transforming, distributing, and controlling apparatuses and "electricity, gas, steam and water supply". However, with this classification alone, it is impossible to distinguish among wind/solar light/solar thermal power, nuclear power, and coal/fire power generation. Through data on the groups in the KSIC and the classes in the KSCO, it is impossible to distinguish and to exclude NPPs and the Four Major Rivers Restoration Project, which are representative of non-green industries, so that they, too, must be included in analysis. Consequently, the South Korean government's announcement that 611 thousand people are employed in "green industries" seems to be an overestimate. 
Table 3. Scale of green jobs (2008).

\begin{tabular}{ll}
\hline Field & Scale of Green Jobs \\
\hline Energy sources & 24,000 \\
High-efficiency energy & 54,000 \\
Greening of the industries and spaces & 251,000 \\
Environmental protection and resource circulation & 102,000 \\
Low-carbon economic activities & 179,000 \\
Total & 611,000 \\
\hline
\end{tabular}

Source: [21].

In "A Study of the Accomplishments and Prospects of the Creation of Jobs in Accordance with the Implementation of the Green Growth Policy", the Korea Development Institute [55] investigated and analyzed accomplishments in the creation of jobs over the past 3 years with respect to projects implemented in accordance with the Five-year Green Growth Plan. According to the results of the study on the details of financial commitment and new and existing jobs regarding the 691 projects included in the five-year plan, the number of directly created new jobs amounted to 156 thousand over 3 years (for 2009-2011), and the total number of jobs including existing ones amounted to 542 thousand. In addition, the number of new jobs created per the financial commitment of 1 billion won was comparatively analyzed, and an average of 2.3 green jobs per 1 billion won were created, with the number of new jobs created in efficient GHG reduction amounting to 7.5, the highest figure from among the 10 strategic tasks (Table 4).

Table 4. Direct employment effect of the Five-year Green Growth Plan.

\begin{tabular}{|c|c|c|c|c|c|}
\hline \multirow{4}{*}{$\begin{array}{l}3 \text { Sectors } \\
\text { Adaptation to climate } \\
\text { change and attainment } \\
\text { to energy independence }\end{array}$} & \multirow{3}{*}{$\begin{array}{l}\text { 10 Strategic Tasks } \\
\text { Efficient GHG reduction } \\
\text { Strengthening of the freedom from petroleum and of energy } \\
\text { independence }\end{array}$} & \multicolumn{2}{|c|}{ Total (2009-2011) } & \multicolumn{2}{|c|}{ No. of Jobs/1 billion won } \\
\hline & & 20,851 & \multirow{3}{*}{87,787} & 7.5 & \multirow{3}{*}{2.1} \\
\hline & & 7104 & & 0.7 & \\
\hline & Strengthening of the capacity to adapt to climate change & 59,832 & & 2.1 & \\
\hline \multirow{4}{*}{$\begin{array}{l}\text { Creation of new } \\
\text { growth engines }\end{array}$} & Development of GT and its transformation into growth engines & 9647 & \multirow{4}{*}{21,117} & 2.3 & \multirow{4}{*}{1.7} \\
\hline & Greening of the industries and fostering of green industries & 1443 & & 0.6 & \\
\hline & Advancement of industrial structures & 7908 & & 1.6 & \\
\hline & Creation of a basis for the green economy & 2119 & & 2.1 & \\
\hline Improvement of the & Creation of green land and transportation & 42,499 & \multirow{3}{*}{46,606} & 3.1 & \multirow{3}{*}{3.1} \\
\hline \multirow{3}{*}{$\begin{array}{l}\text { QoL and strengthening } \\
\text { of national standing }\end{array}$} & Green revolution in everyday life & 4036 & & 3.8 & \\
\hline & Realization of a model nation of world-class green growth & 71 & & 0.2 & \\
\hline & Total & \multicolumn{2}{|c|}{155,510} & \multicolumn{2}{|c|}{2.3} \\
\hline
\end{tabular}

Source: [55].

When the concrete contents of green job creation are examined, green job creation is limited by being concentrated in traditional environmental protection and pollution reduction. Fifty percent of green jobs in South Korea belong to traditional environmental protection and pollution reduction. Traditional environmental protection and pollution reduction is characterized by a large number of jobs in simple labor such as recycling and waste disposal, which provide low working conditions and unstable employment. In the case of South Korea, because jobs in construction projects and public 
employment projects, which provide or require low skills and wages, are included among green jobs. Currently, green jobs in South Korea is taken up by a large proportion of based on existing small environmental industries, with the proportion of employment creation in convergence technology and new technology quite small.

\section{Conclusions and Policy Implications}

It is becoming clear that sustainable development is impossible without separating economic growth from the consumption of resource and energy. Despite the astonishing economic growth that the world has achieved in recent years, an increase in the GDP has failed to bring more abundance and prosperity. Although the economy grew in the 20th Century by pouring in immense energy and materials, this ultimately triggered the global environmental crisis and economic crisis, which means that the ecological transformation of the economy centering on green jobs is the option of the future. The future economy is changing from using large quantities of energy and materials and little labor to saving on energy and materials and using much labor and knowledge. Contrary to what those who focus on growth have claimed, the market, in the end, cannot resolve the problems of the environment and employment alone, which is the backdrop against which the international community and various countries have set out to establish institutions and policies regarding green jobs.

The present study analyzed both the process and contents of South Korea's green job policy. As demonstrated by the present study on green jobs in South Korea; conducted with sustainable development as the analytical framework; it is necessary to search for a paradigm for the ecological transformation of the economy; with a focus on green jobs; instead of being trapped in the existing economic growth paradigm. However; South Korean society's current policy responses to green jobs are problematic in that they lack a long-term vision and excessively depend only on the growth function of the market; seeking to resolve the problems of the environment and employment while being trapped in an economic growth paradigm that exploits fossil energy and the atmosphere's capacity to store carbon. Concepts and awareness in South Korean society still approach green jobs in terms of traditional public employment; construction projects; and nature conservation and remain on the level of creating jobs through market self-regulation in terms of the methodology.

It is necessary to reestablish a concept of green jobs that takes into consideration not only the quantity but also the quality of jobs from the perspective of sustainable development. Although not all green jobs can be high-quality jobs providing or guaranteeing high wages, full-time employment, and expertise, a state with a high proportion of simple jobs with low sustainability in employment, as in the case of South Korea, is far removed from the expansion of the proportion of quality green jobs in the larger scheme. Indeed, green jobs in South Korea are limited in that $50 \%$ of the workers are concentrated in traditional environmental protection and pollution reduction. Employment in traditional environmental protection and pollution reduction consists mostly of simple labor such as recycling and waste disposal, which are characterized by low working conditions and unstable employment. In the case of South Korea, because jobs in construction projects and public employment projects, which provide jobs with low skills and wages, are included among green jobs. Quality jobs as represented by high wages, expertise, and full-time employment must be created in convergence technology, new technology, environmental consulting and services, energy efficiency, and renewable 
energy. It is necessary to have long-term goals regarding employment creation, GHG reduction, and reduction in environmental and energy consumption through green jobs, to green traditional environmental protection and pollution reduction, and to expulse from the market energy sources that are destructive to the environment.

As South Korea's social experience with green job policy shows, green job policy that is not based on the values and spirit of sustainable society can be short-term economic growth policy for economic stimulation. South Korea's green job policy was implemented so as to devote everything to growth as a part of government-led industrialization policy, which is a characteristic of CDS. Limited to the pursuit of short-term competitive efficiency and remaining on the technical level of quantitative growth and expanded employment, the country has yet to transform its economic growth paradigm into one of sustainable development. It is necessary to change the value of market dogmatism, which is projected on to South Korea's green job policy in a distorted form.

Consequently, green job policy must go beyond the level of simple economic stimulation policy and be designed and implemented as an alternative growth model and as a systemic policy that will elevate the developmental level of the market economy system and to heighten democracy. The green job policy of the future must be searched for anew on the level of the ecological transformation of the economic paradigm that will clearly present the Earth's planetary boundaries, strike a balance among economic growth, environmental conservation, and social justice.

\section{Conflicts of Interest}

The author declares no conflict of interest.

\section{References and Notes}

1. Ministry of Environment and National Institute of Environmental Research (NIER). Korean Climate Change Assessment Report 2014; NIER: Seoul, South Korea, 2014.

2. Korea Advanced Institute of Science and Technology (KAIST). National Future Strategy of the Republic of Korea; KAIST: Daejeon, Korea, 2015.

3. Organization for Economic Cooperation and Development (OECD). OECD LaborLabor Force Statistics 2014; OECD: Paris, France, 2015.

4. Statistics Korea (KOSTAT). Economically Active Population Survey; KOSTAT: Daejeon, Korea, 2015.

5. Wei, M.; Patadia, S.; Kammen, D.M. Putting renewables and energy efficiency to work: How many jobs can the clean energy industry generate in the US? Energy Policy 2010, 38, 919-931.

6. Bowen, W.M.; Park, S.; Elvery, J.A. Empirical estimates of the influence of renewable energy portfolio standards on the green economies of states. Econ. Dev. Q. 2013, 27, 338-351.

7. Yi, H. Clean energy policies and green jobs: An evaluation of green jobs in U.S. metropolitan areas. Energy Policy 2013, 56, 644-652.

8. Yi, H.; Liu, Y. Green Economy in China: Regional Variations and Policy Drivers. Glob. Environ. Change 2015, 31, 11-19. 
9. International Labor Organization (ILO). What is a Green Jobs? 2013. Available online: http://www.ilo.org/global/topics/green-jobs/news/WCMS_220248/lang--en/index.htm (accessed on 1 April 2015).

10. United Nations Environmental Program (UNEP). Annual Report 2009: Seizing the Green Opportunity; UNEP: Nairobi, Kenya, 2009.

11. UNEP. Overview of the Republic of Korea's National Strategy for Green Growth; UNEP: Geneva, Switzerland, 2010; pp. 28-30.

12. World Commission on Environment and Development (WCED). Our Common Future; Oxford University Press: New York, NY, USA, 1987.

13. UNEP. Decoupling Natural Resource Use and Environmental Impacts from Economic Growth; UNEP: Nairobi, Kenya, 2011.

14. McMichael, P. Development and Social Change: A Global Perspective; Gyoyangin: Seoul, South Korea, 2013.

15. UNEP. Rethinking the Economic Recovery: A Global Green New Deal; UNEP: Nairobi, Kenya, 2009.

16. Bowen, A. Green Growth, Green Jobs and Labor Markets; World Bank Policy Research Working Paper 5990; World Bank: Washington, DC, USA, 2012.

17. United Nations Environmental Program (UNEP); International Labor Organization (ILO); International Organization of Employers (IOE); International Trade Union Confederation (ITUC). Green Jobs: Towards Decent Work in a Sustainable, Low-Carbon World; UNEP: Nairobi, Kenya, 2008.

18. European Commission (EC). Exploiting the Employment Potential of Green Growth, 2012. Available online: http://eur-lex.europa.eu/LexUriServ/LexUriServ.do?uri=SWD:2012:0092:FIN: EN:PDF (accessed on 1 April 2015).

19. European Commission (EC). Green Jobs and Related Policy Frameworks. An Overview of the European Union, 2013. Available online: http:/www.sustainlabour.org/documentos/ Green\%20and\%20decent\%20jobs20An\%20Overview\%20from\%20Europe\%20FINAL.pdf (accessed on 1 April 2015).

20. Jin, S.H. The Path Dependence of the Lee Myung-bak Administration's National Agenda of "Low-carbon Green Growth". Korean Public Adm. Q. 2013, 25, 1049-1073.

21. Ministry of Strategy and Finance; Ministry of Education, Science, and Technology; Ministry of Culture and Tourism; Ministry for Food, Agriculture, Forestry, and Fisheries; Ministry of Knowledge Economy; Ministry of Environment; Ministry of Labor; Ministry of Land, Transport, and Maritime Affairs; Korea Communications Commission, and Financial Services Commission. A Plan to Create Green Jobs and Train the Workforce: How and Where Will Green Jobs Be Created? Seoul, South Korea, 2009.

22. Jones, R.S.; Yoo, B. Korea's Green Growth Strategy; OECD Economics Department Working Paper 798; OECD: Paris, France, 2011.

23. Presidential Committee on Green Growth. Five-year Green Growth Plan; PCGG: Seoul, South Korea, 2009.

24. Presidential Committee on Green Growth. National Green Growth Strategy; PCGG: Seoul, South Korea, 2009. 
25. The Secondary Basic Energy Plan. Available online: http://www.motie.go.kr/motie/py/td/ energeitem/bbs/bbsView.do?bbs_seq_n=104479\&bbs_cd_n=37 (accessed on 3 July 2015).

26. Kim, K. Concrete Strategies in Preparation beyond the "Green Growth" Declaration. Available online: http://eiec.kdi.re.kr/nara/contents/nara_view.jsp?fcode $=00002000040000100010 \& i d x=7364$ (accessed on 3 July 2015).

27. Yun, S.J. The Ideological Basis and the Reality of "Low-carbon Green Growth". Eco 2009, 13, 219-266.

28. Mathews, J.A. Green growth strategies-Korean initiatives. Futures 2012, 44, 761-769.

29. Baek, J.; Kim, H.S. Is economic growth good or bad for the environment? Empirical evidence from Korea. Energy Econ. 2013, 36, 744-749.

30. Vazquez-Brust, D.; Smith, A.M.; Sarkis, J. Managing the transition to critical green growth: The "Green Growth State". Futures 2014, 64, 38-50.

31. United Nations Economic and Social Commission for Asia and the Pacific (UNESCAP). Green Growth at a Glance: The Way Forward for Asia and the Pacific; UNESCAP: Bangkok, Thailand, 2006.

32. UNESCAP. Low Carbon Green Growth Roadmap for Asia and the Pacific: Turning Resource Constraints and the Climate Crisis into Economic Growth Opportunities; UNESCAP: Bangkok, Thailand, 2012.

33. Christoff, P. Ecological Modernisation, Ecological Modernities. Environ. Polit. 1996, 5, 476-500.

34. Mol, A.P.J.; Sonnenfeld, D.A. Ecological Modernisation around the World: An Introduction. Environ. Polit. 2000, 9, 1-14.

35. Mol, A.P.J. Environmental Transformation of the Modern Order. In Modernity and Technology; Misa, T.J., Brey, P., Feenberg, A.A., Eds.; MIT Press: Cambridge, MA, USA, 2003; pp. 303-325.

36. Mol, A.P.J., Spaargaren, G., Sonnenfeld, D.A., Eds. Ecological Modernization: Three Decades of Policy, Practice and Theoretical Reflection. In The Ecological Modernisation Reader: Environmental Reform in Theory and Practice; Routledge: Oxford, UK, 2009.

37. Presidential Council for Future and Vision. The Path to Green Growth: A Strategy for a Green Economy That Will Change the Future; JoongAng Books: Seoul, South Korea, 2009; p. 42.

38. Yoon, K.J. Reexamining the "Low-carbon Green Growth Policy": Critical Evaluation and Prospects. Korean Policy Stud. Rev. 2012, 21, 33-59.

39. Lee, Y. The Lee Myung-bak Administration's State-Market-Society Relations as Evident from the Theory of Low-carbon Green Growth. J. Legis. Stud. 2010, 30, 67-100.

40. Lee, J. The Paradigm Shift to Green Growth: Accomplishments and Tasks. Korean Econ. Forum 2011, 4, 5-34.

41. Ministry of Knowledge Economy. Industrial Development Strategies for Knowledge- and Innovation-Led Green Growth; Ministry of Knowledge Economy: Seoul, South Korea, 2008.

42. Presidential Committee on Green Growth. Green Growth for All: The Establishment of the Green Growth System at Home and Abroad; 2012 Presidential Committee on Green Growth Work Plan: Seoul, South Korea, 2012.

43. Johnson, C. MITI and the Japanese Miracle: The Growth of Industrial Policy, 1925-1975; Stanford University Press: Stanford, CA, USA, 1982. 
44. Wade, R. Governing the Market: Economic Theory and the Role of Government in East Asian Industrialization; Princeton University Press: Princeton, NJ, USA, 1990.

45. Hong, S., (Ed.) Development Corporations and the Construction State: The Eco-Democratic Reform of Development Corporations and the Prospects for an Eco-Society; Hanul Academy: Seoul, South Korea, 2005.

46. Lee, S.H. Political Economic Review on Low-Carbon Green Growth Strategy of MB Government. Eco 2009, 13, 7-41.

47. Byeon, C.H. Ways of Blocking Neo-developmentalist Local Development Projects. Moonhwa/Gwahak 2005, 43, 140-157.

48. Cho, M.R. The History and Current Status of Developmentalism in South Korea. Environ. Life 2003, 37, 31-53.

49. Song, H.S. A Problem on the Legal Policy to the Low Carbon and Green Growth. Beophak Nonchong 2011, 28, 127-158.

50. Kim, S.; Lee, B. A Critical Assessment on the Organizational Foundations of the Presidential Committee on Green Growth. Korean Rev. Organ. Stud. 2010, 7, 119-150.

51. Korea Labor Institute. An Analysis of the Effect of Green Growth on Jobs: With a Focus on Technological Innovation and the UN Framework Convention on Climate Change; Korea Labor Institute: Seoul, South Korea, 2010.

52. Korea Employment Information Service; Green Jobs: Seoul, South Korea, 2010.

53. U.S. Bureau of Labor Statistics (BLS). Federal Register; BLS: Washington, DC, USA, 2010; Volume 75, Number 182, pp. 57506-57514.

54. Park, C.K. Some Problems of the Green Growth Policy and the Project Saving the Four Major Rivers. Econ. Soc. 2009, 83, 117-142.

55. Korea Development Institute (KDI). A Study of the Accomplishments and Prospects of the Creation of Jobs in Accordance with the Implementation of the Green Growth Policy; National Research Council for Economics, Humanities, and Social Sciences Comprehensive Green Growth Studies ser. no. 11-02-07; KDI: Seoul, South Korea, 2012.

(C) 2015 by the author; licensee MDPI, Basel, Switzerland. This article is an open access article distributed under the terms and conditions of the Creative Commons Attribution license (http://creativecommons.org/licenses/by/4.0/). 